\title{
Erasing the Maternal: Rereading Elizabeth Bishop Patricia Wallace
}

... a perfect erasure disappears along with what is erased. For an erasure to be present for us, we must know that something was there; we must see the traces of the erasure: blottings, blurrings, indentations on the page or in the landscape. Erasure is the forceful writing of loss, absence and rejection. Because we crave to 'be'-in body, in works, in writing-we can never view such erasures dispassionately, as mere blank space.

Stephen Owen, Remembrances: The Experience of the Past in Classical Chinese Literature

IT IS RAINING HERE, in upstate New York. I am rereading after some months Elizabeth Bishop's story, "Memories of Uncle Neddy," which begins with Bishop in Brazil, in Rio in the rainy season: "It is raining in Rio de Janeiro, raining, raining, raining." How remote from mine Bishop's world seems; the hot, sticky air of the tropics, the warm rain falling on a landscape I have never seen. I feel as if I were reading about a dream, a dream-land. And to some degree, as the story unfolds, I see I am.

I remember the opening description of rain from my earlier reading of this story, in part because it reminds me of Bishop's unforgettable sestina, the one set in the Nova Scotia of her early childhood, beginning "September rain falls on the house." Although "Memories of Uncle Neddy" begins and ends in Brazil, most of the story is also about childhood memory, and Bishop's childhood landscape. Together the two landscapes of the storyNova Scotia and Brazil - form, David Kalstone says, the kind of montage Bishop experienced as "a fact of her daily life" while she lived in Brazil. Rio in the rainy season is the "now" of Bishop's story, in which a portrait of her uncle as a child has just returned from the framer. The portrait represents the "then," the memory of the past which invades the present and forms the story's real subject: "And Uncle Neddy, that is, my Uncle Edward, is here. Into this wildly foreign and, to him, exotic setting, Uncle Neddy has just come back, from the framer's." But I had forgotten from my earlier reading of the story that Neddy's portrait is one of a pair. His 
widow, "Aunt Hat," had shipped it from Nova Scotia together with "one of his younger sister's, my mother, in one big crate." Bishop is three pages into the story before disclosing the existence of this second portrait, identified first as Neddy's younger sister, and then, only parenthetically, as "my mother." How had I forgotten the mother's portrait, the presence of that memory, in the story? I think now that I forgot because the story erases her, but erases her imperfectly in the way Stephen Owen suggests, where erasure is the "forceful writing of loss."

These are the facts of Bishop's biography not to be forgotten: her father, William Thomas Bishop, dies eight months after her birth. She moves with her mother to Great Village, Nova Scotia, the home of her maternal grandparents. Her mother is hospitalized several times for mental breakdowns and, in 1916, when Bishop is five, Gertrude Bulmer is permanently institutionalized until her death in 1934. Many years later, in a letter to Anne Stevenson, Bishop wrote simply, "I didn't see her again."

Memory, the pain of memory to be somehow evaded, and the pull of memory which cannot be evaded - this is always at work in the poems and stories which call up Bishop's childhood landscape. A figure, or image, for the nature of that memory appears in one of the memoirs she wrote in the 1960s, "Primer Class," - as the slate on which, as a young child, she wrote her letters and numbers. "What I liked best about the slate was washing it off at the kitchen sink, or in the watering trough, and then watching it dry. It dried like clouds, and then the very last wet streak would grow tinier and tinier, and thinner and thinner; then suddenly it was gone and the slate was pale gray again and dry, dry, dry." How thoroughly this description suspends the process of erasure, how long Bishop holds the persistent streaks before her. The trace of memory remains barely perceptible even as it thins to the point of evaporation. Just such traces of memory incompletely erased appear in Bishop's work at its most personal. The most haunting of those erasures concern the maternal.

Bishop calls the pair of portraits in "Memories of Uncle Neddy" "ancestor children." In Brazil in the 1960s, when Bishop was working on this story, she was old enough to be the parent of those images in the portraits, those youthful versions of her own mother and uncle. And rereading now I 
notice what I hadn't before - the two portraits are mirror images. Neddy stands with "his right leg ... crossed in front of [his left]" while she has "her left leg . . crossed over her right one." She, too, has followed Bishop to Brazil, this "little sister," unnamed here, who is Gertrude Bulmer, Bishop's mother, about nine years old in the portrait, and now, in the story's present, "dead for over forty years." She wears "a small bustle and a gold brooch." Her dress "is dark blue, white-sprigged, with the bustle and other additions purple, and two white frills making a sort of 'bertha.'" She holds a doll. Of her face Bishop says only, "The tintype man has tinted the cheeks of both the doll and my mother a clear pink." My mother- who disappears from "Memories of Uncle Neddy," like the last wet streak on the slate suddenly gone. Fainter and fainter. Barely there. But there.

In Bishop's description, Uncle Neddy's portrait depicts him with cheeks "pink as a girl's or a doll's. He looks rather more like his sisters than like Uncle Neddy." His sister's portrait, despite bustle and brooch, shows a child whose "black hair is cut short all over ... and she looks almost more like a boy than he does." Brother/sister (like father/mother) is a variant of male/female, the slash suggesting a clear division, an opposition where the presence of one term dominates the other. But Bishop here and elsewhere dissolves apparent boundaries into a composite, into confluence. Neddy's portrait seems to replace or substitute for that of the mother's, as Bishop's memory of her uncle covers over, in the story, the memory of her mother. But she is there, showing through in Neddy's pink cheeks.

In one of her late poems, "Santerem," the place where "two great rivers, Tapajós, Amazon" meet, Bishop celebrates "the idea of the place," the idea of two "coming together." There, in such a landscape:

Even if one were tempted

to literary interpretations

such as: life/death, right/wrong, male/female

- such notions would have resolved, dissolved, straight off in that watery, dazzling dialectic.

Two coming together, dissolved in a dialectic: in "Memories of Uncle Neddy," Brazil-Nova Scotia, present-past, uncle-mother, male-female, pain-longing. 
Bishop wrote "Memories of Uncle Neddy" in the late 1960s although she withheld it from publication until 1977 when her uncle's wife had died. (In her fiction Bishop consistently altered family members' names - the "Uncle Neddy" of this story was, in fact, her Uncle Arthur, but of course the name change itself would not have disguised the story's source within her family.) Behind this story lie several other prose works of memory, also written in Brazil, the most important of which is "In the Village" (1953). The Nova Scotian village which was Bishop's early childhood home is the dominant landscape of both stories, although in "Neddy" it surfaces in and through the present of Rio. "In the Village" evokes the Nova Scotia of Bishop's childhood with a kind of radiant immediacy, even as the story obliquely renders her mother's final breakdown. The figure of the mother, referred to only as "she," disappears from "In the Village" as suddenly and mysteriously as she disappeared from the child Elizabeth's life. In that story, the grandmother and aunts stop their sentences when the child Elizabeth is around. They speak in phrases which cover or conceal; they shut the door on their conversations. This hiddenness and silence surrounding the mother's madness become the act of erasing the mother herself. The "story" of the mother appears only as fragments, like the broken china the family unpacks from the mother's trunks. But the memory of the mother leaks through this story and through Bishop's writing like the bottle of perfume also found in those trunks, which "leaked and made awful brown stains," but of whose odor Bishop writes, "Oh, marvelous scent, from somewhere else!" The pain of the mother's disappearance stains memory like the "sad brown perfume" spotting the folded linens. Yet the trace of her in memory - she who was to be forever "somewhere else"-also fills Bishop with longing; the scent her absence leaves is marvelous: "the wonderful smell of the dark-brown stains. Is it roses?"

The most unforgettable trace of the mother appears in Bishop's writing as the scream, which, in the remarkable opening of "In the Village," hovers in the pure skies of Bishop's primal world as a "slight stain." Here is the opening of that great story: 
A scream, the echo of a scream, hangs over that Nova Scotian village. No one hears it; it hangs there forever, a slight stain in those pure blue skies, skies that travelers compare to those of Switzerland, too dark, too blue, so that they seem to keep on darkening a little more around the horizon - or is it around the rims of the eyes? - the color of the cloud of bloom on the elm trees, the violet on the fields of oats; something darkening over the woods and waters as well as the sky. The scream hangs like that, unheard, in memory-in the past, in the present, and those years between. It was not even loud to begin with, perhaps. It just came there to live forever - not loud, just alive forever.

Maternal presence in "In the Village" is partially displaced (as it also was in Bishop's life) to her grandmother and aunts, and to the landscape of Great Village. But these displacements do not fill the blank in the center of the story, the space of the mother. The clothes in the trunk, the perfume which stains the contents, the little ivory embroidery tool the child Elizabeth absconds with and buries in order "to keep it forever," all belong to that space. As does the scream, originating as a particular, hysterical reaction ("The dress was all wrong. She screamed."), become, in memory, synecdoche: the mother, the mother country, the mother tongue.

The dazzling clarity of both landscapes and objects in "In the Village" coexists with a sense of what is hidden, uncertain, full of peril. At one point in the story the child Elizabeth wakes in the middle of the night to church bells ringing a fire; she feels as if the fire were "in the room with me; red flames are burning the wallpaper beside the bed. I suppose," she writes, "I shriek." I suppose: the apparently offhand, self-shielding gesture seems to cover the echo, learned unconsciously, of her mother's tongue, the scream which sometimes hovers on the margins of Bishop's writing.

And then in "Memories of Uncle Neddy," when her memory is stirred by the portrait (by both portraits, I believe), Bishop recalls first the episode in Neddy's life "when his foot got scalded." Neddy has often told her this story of an event which happened before she was born, and Bishop the writer chooses it as a starting place. Does she choose it because it is a story 
of pain, of a stoical response to pain vocalized thus: "On that occasion he had only given one scream"? Does she remember the story as she remembers it because of the scream? "Old stories," Stephen Owen writes of Chinese poetry, "repeat themselves beneath the surface of new stories."

Two sounds are conflated in "In the Village"; they ring out and converge. One is the mother's scream, and the other the clang of Nate the blacksmith as his anvil shapes iron into horseshoes. One is sound which shatters form; one is the sound of work, of the work which creates form. Both belong to Bishop's originating landscape. Ambiguous in nature (like the leaking perfume), the scream is terrifying and incomprehensible; it suggests madness. But it also suggests the open possibility of sound existing before the acquisition of words, like the monotonous, rhythmic, nonsensical sound Virginia Woolf's Mrs. Ramsay croons to her daughter Cam in To the Lighthouse, the sound Margaret Homans calls the mother-daughter language, issuing from and returning to the body. The rhythms of poetry are like such sound-bodily, non-verbal, powerfully communicative.

Yet reading through the collection of Bishop's papers at the college where I teach, what strikes me most is all those drafts. Twenty years spent working on "The Moose"; the blanks left for the exact word or phrase, the lines scratched out and revised, the work that went into those poems! If the power of her writing lies in part in what it communicates without words - in its deeply reverberating rhythms - an equal part lies in the exactness of her language, in the formal shape which contains and reveals her feeling. No wonder Nate's clang is the other of the primary sounds in "In the Village," for it is the "beautiful sound" of shaping, of creating form. Like the twin portraits in "Uncle Neddy," the scream and the clang of "In the Village" form a pair. Which of them is "the pure note: pure and angelic," Bishop describes in her story's central moment? Notice how her description floats, ambiguously, between the two:

\section{Clang.}

The pure note: pure and angelic.

The dress was all wrong. She screamed.

The child vanishes. 
Say that the formal control, the shapeliness and accuracy of Bishop's work, might be what Julia Kristeva calls "the father tongue"-the blacksmith's clang suggesting a world of work affiliated with the blacksmith, the tinsmith (Uncle Neddy's occupation), with her Nova Scotia grandfather who had been a tanner, with her paternal grandfather, a builder and contractor. Then say that the incompleteness, the deep apprehension of the irrational, the shifting indeterminate aspect of language (those shock waves which follow a first reading), equally a part of the experience of reading Bishop, might be called the mother tongue. In Bishop's writing these tongues are interactive, in shifting relation, intertwined.

In Walden, Thoreau writes, "there is a memorable interval between the spoken and the written language, the language heard and the language read. The one is commonly transitory, a sound, a tongue, a dialect merely, almost brutish, and we learn it unconsciously, like the brutes, of our mothers. The other is the maturity and experience of that; if that is our mother tongue, this is our father tongue, a reserved and select expression, too signficant to be heard by the ear, which we must be born again in order to speak." Thoreau's memorable interval separates him from the transitory, "almost brutish" voice affliated with the mother; it suggests an implicit flight from the body into a "select expression" which cannot be heard by the body's ear. In Bishop's work, the tongues which Thoreau here separates flow into each other. Their coexistence undoes Thoreau's hierarchy; Bishop's pure note-"pure and angelic"-is, ambiguously, both mother and father tongues. Her connection to the maternal is never fully severed; the separation forced upon her by loss - and elected, in some sense, through Bishop's own form of exile, travel-is never complete. The pain of that separation and the power of that connection leak through the pages of "In the Village." In her memoir, "The Country Mouse," she renders her subsequent separation from the maternal landscape not as rebirth but as literal sickness for home, as the threat of extinction.

When she was eight, Bishop's paternal, Boston grandparents removed her from her maternal grandparents and her home in Nova Scotia. In her account of this event in "The Country Mouse," written in 1963 but not published until after her death, she writes she felt she had been "kid- 
napped," in order "to be saved from a life of poverty and provincialism, bare feet, suet puddings, unsanitary school slates, perhaps even from the inverted r's of my mother's family." From unstable forms of writing and speaking-unsanitary school slates and inverted r's-Bishop's father's family thinks to rescue her. From the behind-the-times, out-of-time maternal landscape of Great Village, the paternal grandparents "kidnap" Bishop in order to socialize her.

What does the child Elizabeth learn in the house of her father (her father's father)? She learns the social realities of money and class: a chauffeur meets them at the train, a schoolmate who comes home with Bishop asks, " 'Who lives in that part of the house?" "Social consciousness," Bishop writes, "had struck its first blow." She learns the compulsory identity dictated by the nation-state (the war is on; in school she is forced to sing war songs and pledge allegiance to the flag - "I didn't want to be an American." Bishop's adult response to this was to become a traveler). And she learns the social reality of gender in ways she had been protected against in Nova Scotia: 'there seemed to be much more to being a 'little girl' than I had realized; the prospect was beginning to depress me." These realities, so unlike the seamless world of Great Village, require that she think of the world, and herself, in a different way. "The house was gloomy... . There was something ominous, threatening, lowering in the air."

Elizabeth, in "The Country Mouse," sees herself suddenly "in the long mirror: my ugly serge dress, my too long hair, my gloomy and frightened expression." Is it making too much of this moment to think of the "mirror stage," that moment when the child experiences herself as separate from the mother's body? Lacan identifies this moment with language acquisition, because it is the moment when the child differentiates himself from an unmediated connection (and communication) with the mother's presence. But in Bishop, the shock of experiencing the self as separate follows long after the acquisition of words. Here, in this memoir, the moment follows Elizabeth's attempt to see the world through her (grand)father's eyes ("I reached gingerly over ... to get his eyeglasses"), as if with that vision she saw herself separate and unacceptable in the paternal order of things. This moment is suffused with pain, as is the moment which concludes this memoir, where the specific setting-the dentist's 
office-literalizes the larger pain the passage expresses. Bishop would later rewrite this experience as her poem "In the Waiting Room." Here, in the conclusion of "The Country Mouse," the emphasis falls on the "absolute and utter desolation" she experiences in the waiting room when "I felt ... myself" (the ellipses here are Bishop's). "Something" says to her " "You are you .... you are you and you are going to be you forever." "What follows the child Elizabeth's earlier glimpse of herself in the mirror is this: "Then I became ill. First came eczema, and then asthma."

Living in her father's house silences the child Elizabeth's connection to the mother tongue, and disconnects her from the mother country. The force of that silence and disconnection makes her ill (a "whole chorus throbbing at our ears / like midges," Adrienne Rich writes, teaches us "that it is unnatural, / the homesickness for a woman"). The child in "The Country Mouse" resists the structures of the father's house, resists its language through her own silence. The writer Bishop masters the father's language, and so becomes a writer; she also resists it, and so becomes a writer worth reading. Through an affliation with the mother country (Nova Scotia) and the mother tongue, Bishop preserves in her writing an instability, even as she forges a style I have often felt to be "reserved" or "select." (I remember that in "Primer Class," where I found an image for memory in the school slate, Bishop describes herself as a young child who found writing enjoyable precisely for its instability, its shifting, indeterminate expression: "It was wonderful to see that the letters each had different expressions, and that the same letter had different expressions at different times.")

In Worcester, in her paternal grandparents' house, Bishop does what women learn to do in the house of the father: she listens. Like Beppo the Boston bull terrier (the occupant of the house with whom she most closely identifies) she understands "by tone of voice rather than by words." This ability to understand tone is, of course, indispensible to poetry; it is what Robert Frost called "the sound of sense," a sound like "voices behind a door that cuts off the words." The child Elizabeth listens with the ear of the body, the same ear which will make her a poet. ("The ear is the only true writer and the only true reader," Frost also said.) Her capacity to understand and to create nonverbal meaning belongs to her connection to 
the maternal: to the scream, to the voices of aunts and grandmother whispering behind doors, to the croonings of her maternal aunt in "In the Village" or her maternal grandmother (as recollected in the story "Gwendolyn"), who rocked her in her lap and sang her "watery" Baptist hymns. (Bishop reenacts this maternal form of communication in her poem, "At the Fishhouses," when she sings just such Baptist hymns to a seal. Yes, a seal.) But "The Country Mouse" describes Bishop's exile from the maternal, and her painful inability to speak her feelings in this house of the father. "I rarely spoke," she writes of conversation at table. One day, sitting at dinner, she decided "I had something to contribute" and offered " "The last time my aunt in Nova Scotia bought a pair of shoes, they cost three dollars.' Everyone laughed." Nova Scotia - distinctly female ("my aunt") - translates imperfectly in this house, appears inadvertantly ridiculous, nonsense. "I lost my courage about making conversation at the dinner table," Bishop writes, "and I have never regained it."

These prose pieces of Bishop's are so often painful. In them there are flashes of the humor of her poems (as in, for example, her description of Beppo "punishing himself" for his puddle of vomit on the floor-"it was all his own idea, his peculiar Bostonian sense of guilt"), but the humor is very much subdued. I find them sometimes wrenchingly sad.

In "The Country Mouse," Bishop writes, "I felt myself aging, even dying." The reserved and select language of that house-with its structures of dominance (nation, class, gender)-does not afford expression of her deepest feelings. It offers no words for her experience. Bored and lonely, she lay at night "blinking my flashlight off and on, and crying." In this often heart-breaking, intermittently comical piece, the pulse of the flashlight seems a signal for help, a signal in the form of a nonverbal rhythm. At this point in her memoir Bishop quotes the poet Louise Bogan: "At midnight tears / Run into your ears." Isn't this couplet a little dance around the edges of meaning? Isn't it a kind of rhyme disruptive of logic, expressive of the unspecifiable pain Bishop remembers feeling? It is language breaking through reserve, poetry as sound connected to the maternal.

In "Transcendental Etude" Adrienne Rich writes: 
At most we're allowed a few months of simply listening to the simple line of a woman's voice singing to a child against her heart. Everything else is too soon, too sudden, the wrenching-apart, that woman's heartbeat heard ever after from a distance, the loss of that ground-note echoing whenever we are happy, or in despair.

Once Robert Pinsky characterized Bishop's idiom this way: "the seemingly restrained yet relaxed sentences, startlingly flexible in practice, framing the diction of a respectable, alert American tourist, educated but not pedantic, sophisticated but very quiet about that sophistication." But what's omitted from this account is the unpredictable, sometimes disruptive way Bishop unsettles meaning, the power of her rhythms to communicate unspoken longings, to suggest something that aches and burns, to evoke what we hear from voices behind doors, or from far in the back of the bus as it travels through the night. This power in Bishop's work has its source in the mother tongue, as her power simultaneously to shape sentences "restrained yet relaxed" belongs to her mastery of the father's tongue.

Social laws govern much of the grandparents' world in "The Country Mouse." Likewise, social laws govern the use of language, teach us to be "select." But each speaker and writer who learns those laws can also break them, can creatively reshape language through her local, specific, distinctive usage. The writer Bishop is a "master" of language, a master of its social and formal nature (who would imagine this witty, gifted poet as someone who has never regained her courage "about making conversation at the dinner table"? Though I believe her). But her mastery is in constant, shifting relation to the disruptive, the unspecifiable, to what can't be mastered. This, of course, is the subject of her astonishing late villanelle "One Art"; its central rhyming pair-master/disaster-comes out of the deepest centers of Bishop's life and writing.

What can't be mastered? Madness, of course. A maternal presence which is always "somewhere else." A scream which stains the skies of childhood, 
but whose stain is so embedded in the deep blue of those skies ("the color of the cloud of bloom on the elm trees, the violet on the fields of oats") that imperfection and perfection are composite; the flaw can't be separated from the beauty. What can't be mastered is the pain of loss (although "One Art" is about "the art of losing"). What can't be fully masteredwhat remains incomplete, not fully accessible to form, forever both here and "elsewhere"-is the maternal sound, the mother tongue. Mastery itself seems to be affliated with the world of the father, with the power to bring (or sometimes force) things into shape (the blacksmith's shop, Neddy's tin shop, the paternal family business-building and contracting). Learning this power is part of what enabled Bishop's survival; that the objects in the world around her took such distinct shape - that she saw those objects so distinctly and could describe them so exactly-created a way of mapping a world and a life. But in Bishop this power remains in touch with what defies it, with the maternal which resists a single shape. The power of the mother tongue in her work is like the "oh! of pain" the child Elizabeth hears in "In the Waiting Room," the poem in which she rewrote the memory that concludes "The Country Mouse." The cry of pain does not appear in the earlier version of the experience; here, in the poem, it is central. At first Elizabeth takes the sound to be the voice of her aunt but then, she writes, "What took me / completely by surprise / was that it was me: / my voice, in my mouth." That disruptive "cry of pain" breaks through categories of distinction. Bishop calls it "the family voice / I felt in my throat." The family voice, the "oh!" of pain, the scream.

On the slate of Bishop's memory, one of the streaks, shiny as a tearstain, is the maternal. Each time it is erased, it reappears.

It reappears, under erasure, in "Memories of Uncle Neddy." As that story opens the Brazilian sea is "blurred with rain"; everything is damp. Rain is "seeping in under the french doors and around the window frames" and "at flood tide," Bishop writes, the sea may rise to "the base of the apartment building as it's been known to do." Rain brings on mold and mildew, brings on Bishop's asthma. Something seems at work in this story which is not in the writer's control (not under her mastery). Something leaks through like the rain, an insistent wetness which also recalls 
the flood of birthwaters. A flood of memory prompted by the family portraits sends Bishop back into her Nova Scotia landscape, subject to change and loss. What leaks through the story's structures, seeps like rain through the doors, is the memory embodied in the second portrait, the erased mother.

After the portraits of her uncle and his sister arrived in Brazil, Bishop writes she "can't stop thinking about him." Am I to believe she can stop thinking about her mother, whose portrait she has also unpacked from the crate? Does she turn the memory evoked by the portraits in the direction of Uncle Neddy because the memory of the mother is too powerful, too disruptive to be framed as a story? Or is it that the memory of her mother, even when packed away, remains a constant part of her world, whereas she is surprised to find herself remembering Uncle Neddy? And finding a connection, as David Kalstone astutely suggests, with Neddy's life "blighted by drink and irresponsibility" and her own "anarchic side." For this connection the story can provide a workable frame.

Frames are an issue in "Uncle Neddy." The portraits arrive in frames "a foot wide, painted and repainted with glittery, gritty paint." Bishop replaces them with "narrow, carefully dulled, gold ones, 'modern,", explaining that she has "reduced" them to "the scale suitable for hanging in apartments." Perhaps she needs to reduce the power those "ancestor children" have over her, to dull the memories they invoke, memories which threaten not to stay safely within a mastered past. The ancestors of these portraits narrow the gap between "then" and "now." "[Y]oung and clean," Bishop's uncle appears to her "with nothing between us but a glaze of old-fashioned varnishing." The "glaze" of varnish is like a membrane, or a window-it's a variant on a recurring set of images in Bishop's work, all of which thinly separate her from what she sees. But sometimes the mediating element cracks, or vanishes. (In her story, "Gwendolyn," she watches the funeral of her childhood friend through the window, gazing at the coffin "with Gwendolyn shut invisibily inside it forever, there, completely alone on the grass by the church door"; in that moment feels herself there, shut up forever, and she runs "howling to the back door, out among the startled white hens, with my grandmother, still weeping, after me.") The unpredictable power of memory can remove the glaze of var- 
nish that holds the past in place. Therefore, unpacking the portraits in "Memories of Uncle Neddy" is a potentially dangerous activity. It is the portrait Bishop deflects attention from, doesn't write much about, that presents the more powerful threat of memory to the present. The "glittery gritty" memory of the mother hovers at the edges of the story, in an incompleteness just out of reach. She appears as a trace, an evaporating streak on the slate of writing and memory. "[D]id she," Bishop wonders of the little-girl mother, "have only the one dress, for dress-up?" Did she, did she?

Stephen Owen writes, "We only forget what is 'perfect,' finished. . . . Our repetitions are the scars of some incompletion: something in our life stutters. Something is not content simply to be and to have been, but must try to be again, and never successfully and finally." Traces of erasure are like scars, the scars of stories that keep repeating themselves in Bishop's work.

Within its larger frame "Memories of Uncle Neddy" repeats versions of Bishop's primary stories, stories which can't be forgotten or finished. Stories which tell, in one way or another (and sometimes comically), of the disappearance of a loved person or object, of abandonment or engulfment, of loss. And of survival - the child's survival, the woman's, the writer's. Her work reinscribes floods, shipwrecks, and drowning, and sometimes a baby.

Her Uncle Neddy's library, as Bishop remembers it in the story, was chiefly interesting for its collection of books about the sinking of the Titanic. She and her uncle shared a fascination with this form of catastrophe: "in the dining room, facing his place at the table, hung a chromograph of the ship going down: the iceberg, the rising steam, people struggling in the water, everything, in full color." Among Bishop's maternal ancestors, her editor Robert Giroux tells us, was a great grandfather, "master and part owner of a sailing vessel lost at sea off Cape Sable Island." And of course the sea is part of what defines Bishop's two central landscapes, Nova Scotia and Brazil. 
Shipwrecks, floods, and babies. Their incidental, it seems, appearance in "Uncle Neddy" repeats in incomplete form some older, unfinished story. In one of Bishop's first published works of fiction, "The Farmer's Children," four children are pushed outside by their mother, and in the cold they play "at raft and shipwreck." Bishop later called this "a very bad story," and, measured against the standard of her work, she was right. But its very failures of expression throw the stutter of repetition into relief. This is the game the children play: there's a shipwreck, "the baby, Gracie Bell" is imagined to be drowning ("Gracie Bell," the initials G.B. are those of Bishop's mother, Gertrude Bulmer). One of her older brothers pretends to swim to her rescue, while another calls out "over and over 'Now the ship is sinking inch by inch! Now the ship is sinking inch by inch!" "The older brother lifts the baby in his arms, and turns "firmly back, treading water with tiny up-and-down steps." And then, Bishop writes, "Gracie Bell shrieked and he repeated, 'I'll save you, Gracie Bell. I'll save you, Gracie Bell'...." Who is saving whom here? Is the older brother in this story a version of Bishop rescuing one who shrieks, G.B.Gertrude Bulmer - from the wreckage of mental breakdown and from the flood of time? Or is Bishop the baby, imagined to be drowning, the baby who shrieks? Is she both?

In "Memories of Uncle Neddy" another story of a flood and a baby resurfaces, another baby is in need of rescue, this time because forgotten. Like the earlier incident of Neddy's scalding (a version of the oh! of pain), this is, Bishop says, a family story told to her many times: how earlier in Nova Scotia the river had flooded (as in the "now" of the story the sea threatens to flood the apartments of Rio), warning had been given, and "in the excitement of rescuing older children, the clock, the cow and horse, my grandmother forgot the latest baby (later my aunt), and my grandfather had dashed back into the house to find her floating peacefully in her wooden cradle, bobbing over the kitchen floor."

The baby bobbing in the water: cradled by amniotic fluid, surviving happily in that element. The baby forgotten by the (grand)mother, in need of rescue. But rescue isn't without consequences. In "Uncle Neddy" the story of the forgotten-then-rescued baby ends parenthetically "(but after 
this the poor baby had erysipelas)." Erysipelas - an acute disease of the skin, an inflammation, the consequence of being forgotten and rescued. I think of Bishop's eczema and asthma, so fierce in her childhood that they prevented her from attending school, whose onset occurred when her father's parents "rescued" her from the maternal ground of Nova Scotia and from the unstable mother's tongue.

Of course in the story within "Uncle Neddy" the baby floating peacefully in her cradle was in imminent danger of drowning. And of course the image of the baby-self bobbing in amniotic waters is one of both safety and constriction: such is the ambivalence toward the maternal many daughters feel. For Bishop, given the conditions of her early childhood -in particular her mother's insanity and disappearance from Bishop's life-this ambivalence was especially unresolved and powerful. In her work the maternal memory, the maternal body and voice indispensible to that memory, carries shifting meanings. It is a composite, feared and desired, the source of comfort and of threat.

Bishop's account of a nightmare in "Uncle Neddy" can be read as one version of the maternal body: she sees the door of Neddy's tin shop "blocked by a huge horse, coming out. The horse filled the doorway, towering high over me and showing all her big yellow teeth in a grin. She whinnied, shrill and deafening; I felt the hot wind coming out of her big nostrils; it almost blew me backwards." This is the night mare, her big yellow teeth, her shrill whinneying. Too big, she fills all the space and blocks any exit. Uncle Neddy (Bishop's dream double) has his "escape cut off by the fearful animal." The dream suggests a monstrous female body, whose hot breath threatens to blow Bishop backward into the past, whose huge body blocks any exit from that past. The threat of this body must be deflected and erased. In contrast there's this description from "In the Village" of the "attendant horse" who patiently waits in Nate the blacksmith's shop: "He is enormous. His rump is like a brown, glossy globe of the whole brown world. His ears are secret entrances to the underworld. His nose is supposed to feel like velvet and does, with ink spots under milk over its pink. ... On each temple is a clear glass bulge, like an eyeball, but in them are 
the heads of two other little horses (his dreams?), brightly colored, real and raised, untouchable, alas, against backgrounds of silver blue. His trophies hang around him and the cloud of his odor is a chariot in itself."

This animal belongs not to the nightmare world but to daydream and reverie; he is a dream of a horse. While he is enormous, his enormity is entirely without threat. He is marvellous, placid, controllable (the description ends with his backing into the "shafts of his wagon"). His odor is a chariot, his nose feels like velvet. The details of Bishop's descriptions are always important, including the specifics of gender. James Merrill recalls a telephone call from his friend, David Kalstone, to talk about Bishop's poem "The Moose." Merrill writes, "I mention the stanza that evokes a household at night, the kitchen where a dog sleeps, tucked in his shawl. 'Tucked in her shawl,' David corrects, the smile audible."

But the night mare is just one version of the maternal body which appears in Bishop's work in many forms-as comforting (like the dog in her shawl, or the grandmother's lap), as "grand, otherworldly" and yet "Perfectly harmless" (in “The Moose": - “'Look! It's a she!'”), and as desired. The maternal is the unspecificable aspect of Bishop's writing which, like the letters formed by Bishop's childhood hand in "Primer Class," can have "different expressions at different times." It exists in her work right alongside her distinctive exactness and clarity. I might say that the maternal is what is unreadable in Bishop. For how do we read the traces of the mother's memory which appear as the scream, or as the apparently marginal detail of a poem or story? How do we read her incomplete presence in "Uncle Neddy"; her portrait, Bishop tells us, is "unsigned and undated, probably the work of an itinerant portrait painter." (I haven't a doubt the real portrait was precisely unsigned and undated, was the work of an itinerant painter. Bishop loved to insist on accuracy. But these literal details suggest something missing that's inseparable from other, less specifiable causes.) It seems possible to me that maternal memory appears unreadable in Bishop because, in part, she did not want us to read it. At some level, the memory of the mother seems to have existed for her as what Bachelard calls "pure recollection, the image that belongs to us alone, we do not want to communicate it; we only give its picturesque details. Its very core, however, is our own, and we should never want to 
tell all there is to tell about it." In "Uncle Neddy" we get the "picturesque details" of the mother's portrait - the dress, the doll, the shoes. But the portrait disappears from the story before we can come any closer. Bishop doesn't tell all there is to tell. She never does.

For all of Bishop's descriptive accuracy, her careful and attentive eye, her clarity, there are concealments. Reticence and omission are aspects of her style. (Take the terse description of Friday in "Crusoe in England": "Friday was nice. / Friday was nice, and we were friends. / If only he had been a woman!" Seeing the poem before publication, James Merrill asked her"idiotically," he says - "if there couldn't be a bit more about Friday? She rolled her eyes and threw up her hands: Oh, there used to be-lots more! But then it seemed ... [sic]. And wasn't the poem already long enough?") Her landscapes are especially marked by concealment, with their hidden spaces the poems both gesture toward and protect. "Cape Breton" is one of the most suggestive of such poems, where the landscape verges on disappearance into the mist. Bishop wrote this poem after a trip to Cape Breton in 1948, following visits to Nova Scotia in the summers of 1946 and '47, visits which marked a return to her maternal landscape for the first time in many years. Like "At the Fishhouses" from the same period, "Cape Breton" suggests the resonance and mystery which emanate from this landscape in Bishop's life and work; it is a place of waters where boundaries are unclear:

The silken water is weaving and weaving, disappearing under the mist equally in all directions. lifted and penetrated now and then by one shag's dripping serpent-neck, and somewhere the mist incorporates the pulse, rapid but unurgent, of a motorboat.

The pulse heard from within this watery landscape suggests to me not only a motorboat but a heartbeat; it suggests this landscape is also a body, one with secret interiors, with a core which resists description. "Whatever the landscape had of meaning," Bishop writes, "appears to have been abandoned / unless the road is holding it back, in the interior / where we cannot see/ where deep lakes are reputed to be...." In the often remarkably 
detailed and specific description of this poem, where we see exactly the "occasional small yellow bulldozers" or the "little white churches" which appear "dropped into the matted hills/ like lost quartz arrowheads," something is held back.

As "Cape Breton" unfolds, the poem spins deeper and deeper into its interiors. When, in the fourth stanza, a small bus discharges its passengers, this is what follows:

It stops, and a man carrying a baby gets off, climbs over a stile, and goes down through a small steep meadow, which establishes its poverty in a snowfall of daisies, to his invisible house beside the water.

The parent and child, the small meadow, the snowfall of daisies, the house by the water: these are the elements of a dream world, a world safe, peaceful, lovely, and hidden. This world belongs to Bishop's interior, as well as to Cape Breton's. But even here some portion of the landscape remains out of sight, out of reach. A man carries a baby to his "invisible house." And rereading Bishop now, I can't help thinking, where is the mother? (As in her late poem, "Pink Dog," Bishop can't help asking the dog "Where are your babies?") Did she die in childbirth? Is she waiting, an invisible presence in the invisible house? Has she been erased into the landscape: the meadow with flowers, the house by the water? Is it her heartbeat which is "rapid but unurgent"? Are the traces of the maternal what the landscape is holding back?

In the last line of "Cape Breton" "an ancient chill is rippling the dark brooks." This chill reverberates in what I think of as a companion poem from the same period, "At the Fishhouses." Here is also a place where land and water meet, one whose beauty bears "some melancholy stains," like those Bishop sees on an ancient capstan. The entire landscape is as unfathomable as the sea the poem so powerfully describes, concluding with these lines:

It is like what we imagine knowledge to be:

dark, salt, clear, moving, utterly free, 
drawn from the cold hard mouth

of the world, derived from the rocky breasts

forever, flowing and drawn, and since

our knowledge is historical, flowing and flown.

In his discussion of the literary friendship between Bishop and Robert Lowell, David Kalstone tells us that when Lowell first read "At the Fishhouses" (in The New Yorker), he wrote Bishop that the word "breast" in the poem's close seemed "a little too much in its context perhaps; but I'm probably wrong." Kalstone comments: "What [Lowell] picked up, of course, was the flicker of human drama, of a vestigial implacable female presence behind the scene. . . "The trace (hidden but present) of an enduring and unfixable female presence stains this poem and ripples the surfaces of Bishop's work; to come in touch with it can cause your bones to "begin to ache" and your hand "to burn" ("At the Fishhouses"). The "ancient chill" rippling the dark brooks also burns; it potentially becomes not only maternal memory but the ripple of the erotic in the body and the world.

Ripples, hidden interiors, wetness, warmth, fire-these are some of the traces in Bishop of a maternal erotic, of a desired female body. As in her poem "The Shampoo" where "rings around the moon" appear while the poet washes the hair of a "dear friend," or in the elusive "O Breath," with its "equivocal" association of breast and ripple. As in "Song for the Rainy Season" (set in Petropolis, Brazil, at Samambaia, the name of the house Bishop shared with Lota de Macedo Soares), which begins "Hidden, oh hidden / in the high fog / the house we live in." Hidden, the house with its brooks and waterfalls lies wrapped "in a private cloud"; hidden, the house lies open ("House, open house / to the white dew"); it houses "the warm touch/ of the warm breath, maculate cherished." Or as in the remembered moment of "In the Village" when her younger aunt (her mother's sister) comes into Elizabeth's room to reassure her about the fire. Gets into bed with Elizabeth, "says to go to sleep, it's way up the road. The men have to go; my grandfather has gone. It's probably somebody's barn full of hay, from heat lightning. It's been such a hot summer there's a lot of it. The church bell stops and her voice is suddenly loud in my ear over my shoulder ... Wagons rattle by. 'Now they are going down to the 
river to fill the barrels,' my aunt is murmuring against my back. The red flame dies down on the wall, then flares again." In such a moment, the rhythmic murmur of the female voice merges with the female body. Like other moments in "In the Village," this one makes the house a world of women: grandmother, aunts, sewing lady. The men are gone to fight the fire. In the red flame on the wall, the hot summer, the heat lightning, the murmuring female voice experienced as if it were touch, a powerful female erotic makes itself felt, makes itself heard.

Eros and memory, like fire and water, potentially both generative and destructive. For Bishop, the most powerful forms of both are linked to the maternal body, the mother country, the mother tongue.

At the end of "Memories of Uncle Neddy" Bishop returns to the portraits - the frame of her story and mine - in which the child Neddy and his little sister might seem to be "about to start out." The portraits appear, then, as beginnings (here, in the ending), signs of an as yet unfulfilled, open possibility. "I am going to hang them here side by side," Bishop continues, "above the antique (Brazilian antique) chest of drawers. In spite of the heat and dampness, they look calmly on and on, at the invisible Tropic of Capricorn, at the extravagant rain still blotting out the southern ocean." The same portraits continued to hang side by side in the rooms of Bishop's life; after she left Brazil they would turn up in the living room of the last of her "houses," her apartment on Lewis Wharf in Boston. Mirror images. An unseparable pair. Uncle and mother, fear and desire, clang and scream, mother and father tongues. In the watery, dazzling dialectic of Bishop's writing, intertwined.

"I love having the pictures," Bishop wrote her aunt in 1957. "The little girls think they're my mother and father."

\section{ACKNOWLEDGEMENTS}

Colleagues in a Vassar multidisciplinary seminar on feminist scholarshipMiriam Cohen, Eileen Leonard, Deborah Dash Moore and Mary L. Shan- 
ley - read an earlier draft of this essay and contributed valuable suggestions and criticisms. The fact that all of these women are scholars in disciplines other than my own made their insights into Bishop's work especially daunting and exciting.

All quotations from Bishop's poetry and prose are from the two collections, Elizabeth Bishop: The Complete Poems 1927-1979 and Elizabeth Bishop: The Collected Prose. 